\title{
First report of Leptoxyphium kurandae infection on Thespesia populnea (L.) Sol. ex Correa in India
}

\author{
Sripriya Nannu Shankar ${ }^{1} \cdot$ Bhuvaneswari Srinivasan $^{2} \cdot$ Balamurugan Ananthakrishnan $^{1}$. \\ Udaya Prakash Nyayiru Kannaian ${ }^{3}$
}

Received: 8 September 2018 / Accepted: 15 March 2019/Published online: 27 March 2019

(C) Società Italiana di Patologia Vegetale (S.I.Pa.V.) 2019

Keywords Leptoxyphium kurandae $\cdot$ Thespesia populnea $\cdot$ Sooty mould $\cdot$ Pathogenicity

Sooty mould was observed on Thespesia populnea in different districts of the state of Tamil Nadu, India, during the months September-November in the years 2016 and 2017. The growth was sooty, black and velvety, with the fungal crustaceous coating at the junction of petiole and leaf blade, along the midrib at the abaxial side of the leaves. The infection was superficial on the lower epidermis of the leaves. The conidiomata $(n=100)$ were synnematous, erect or slightly curved with three parts, viz., dark brown bulbous base $(30-50 \times 25-35 \mu \mathrm{m})$, cylindrical part (pale brown to olivaceous brown with parallel synnematous hyphae $60-100 \times 12-15 \mu \mathrm{m}$ ) and funnel shaped hyphal apex $(30-50 \times 25-40 \mu \mathrm{m})$. The conidiophores were subcylindrical to subulate, $0-2$-septate, $15-25 \times 2-3 \mu \mathrm{m}$, aggregated at the apex of synnema and diverged near the apex. Conidiogenous cells were terminal, monophialidic, $7-10 \times 2-2.5 \mu \mathrm{m}$, tapering to a truncate apex, with periclinal thickening and visible collarette. The conidia were broadly ellipsoid with

Electronic supplementary material The online version of this article (https://doi.org/10.1007/s42161-019-00291-w) contains supplementary material, which is available to authorized users.

Udaya Prakash Nyayiru Kannaian

nkudayaprakash@gmail.com

R and D, Marina Labs, Nerkundram, Chennai 600107, India

2 Department of Botany, Bharathi Women's College, Broadway, Chennai 600108, India

3 Deparment of Biotechnology, Vels Institute of Science, Technology and Advanced Studies, Pallavaram, Chennai 600117, India rounded ends, $0-1$ septate, eguttulate to guttulate smooth hyaline slimy masses, at the apex of synnema (4-)6$7(-9) \times 2-3 \mu \mathrm{m}$ (Hughes 1976). Based on the morphological and microscopical characters (Matsushima 1989), the sooty mould was identified as Leptoxyphium kurandae Crous \& R.G. Shivas (Crous et al. 2011). The ITS sequence of the culture amplified using ITS1 and ITS4 primers was deposited in GenBank (Accession No. MH756173). From BLASTn and phylogenetic analysis, the obtained sequence showed $99 \%$ similarity to the ITS sequence of the type, CPC 17274 (JF951150). Pathogenicity studies according to Koch's postulates were carried out through field inoculation of viable spore suspension $\left(1 \times 10^{6}\right.$ conidia/ml $)$ of $L$. kurandae on the leaves of one-year-old healthy T. populnea plants. The leaves were covered with sterile polythene bags for $24 \mathrm{~h}$ and further maintained in greenhouse $\left(28 \pm 2{ }^{\circ} \mathrm{C}\right)$ for 15 days. The plants were found to be asymptomatic. This is the first report of L. kurandae infection on T. populnea.

\section{References}

Crous PW, Groenewald JZ, Shivas RG, Edwards J, Seifert KA, Alfenas AC, Alfenas RF, Burgess TI, Carnegie AJ, Hardy GS, Hiscock N (2011) Fungal planet description sheets: 69-91. Persoonia 26:108 Hughes SJ (1976) Sooty moulds. Mycologia 68(4):693-820

Matsushima T (1989). Matsushima Mycological Memoirs No. 6. Published by the author, Kobe

Publisher's note Springer Nature remains neutral with regard to jurisdictional claims in published maps and institutional affiliations. 